\title{
The Impact of Political Connections on the Performance and Solvency of Canadian Financial Institutions
}

\author{
Saidatou Dicko ${ }^{1}$ \\ ${ }^{1}$ School of Management, Université du Québec à Montréal, Montreal, Canada \\ Correspondence: Saidatou Dicko, School of Management, Université du Québec à Montréal, Montreal, QC., H2X \\ 3X2, Canada. Tel: 1-514-987-3000\#3848. E-mail: dicko.saidatou@uqam.ca
}

Received: August 18, 2016

Accepted: September 22, 2016

Online Published: October 25, 2016

doi:10.5539/ijef.v8n11p1

URL: http://dx.doi.org/10.5539/ijef.v8n11p1

\begin{abstract}
This article's main goal is to analyze the impact of political connections on the financial performance of Canadian financial institutions. Data on Canadian financial institutions from the S\&P/TSX Composite Index over a five-year period was analyzed, and the results demonstrate that contrary to previous studies on companies in other industries, political connections had a negative influence on solvency, return on assets and return on equity for these Canadian financial institutions. Only the market-to-book ratio was positively and significantly influenced by political connections.
\end{abstract}

Keywords: political connections, performance, solvency, Canadian, financial institutions

\section{Introduction}

Crises and financial scandals have undermined public and investor confidence in the financial system worldwide. In the Canadian context, multiple corruption and collusion scandals have highlighted the problem and demonstrated the links between politics and business. These links, known as political connections, can be a major governance challenge for corporations.

In the news as well as in the scientific research, financial institutions have until now been virtually excluded from the debate on corporate political connections. Yet financial institutions control financial resources, the most important factor behind such connections. The purpose of this article is therefore to analyze the behavior of politically connected financial institutions in relation to the most relevant aspects of their governance, solvency and financial performance. The main question is whether politically connected financial institutions show a different level of solvency and performance than non-politically connected financial institutions.

Financial institutions play a major role in the economy. Financial experts have emphasized the role of banks during the financial crisis in 2008 (Note 1) and the need to improve their solvency in order to protect investors and markets and avoid new crises. The results of this research provide reference points for securities on the changing levels of risk and solvency of financial institutions, especially after the 2008 crisis, and help assess the effectiveness of new regulatory measures to improve solvency, particularly in the context of the Basel Accords and the Financial Stability Board (FSB). In the past year, the FSB has proposed raising the banks' capital ratio to $20 \%$, which is well above the requirements of Pillar 3 of the Basel framework (Note 2). More importantly, this study demonstrates the existence and impact of political connections in Canadian financial institutions, which is a first at this time.

The results of regression analysis on Canadian financial institutions (banks and insurance companies) from the S\&P/TSX Composite Index between 2010-2014 show that return on assets (ROA), return on equity (ROE) and solvency were negatively and significantly influenced by political connections. Only the market-to-book ratio was positively and significantly influenced by political connections. These results suggest that Canadian financial institutions do not benefit directly from their political connections. However, the market appears to value the political connections of financial institutions.

\section{Theoretical Foundations}

According to resource dependence theory, every organization needs a number of key resources to operate and be successful. However, these resources are generally external and controlled by people who are outside of the immediate environment of the business organization, which means that each organization depends on the 
environment to obtain the resources necessary for its success. Breton and Pesqueux (2006, p. 12) argued that "[t]he corporation is, firstly, a social institution [...], which is using resources belonging [to] and provided by its surrounding society." Organizations may use a variety of means to access these resources, including appointing individuals with social relationships or connections to its board of directors (Pfeffer \& Salancik, 1978; Pfeffer, 1981; 1982).

Social capital theory stipulates that each individual has a number of social relationships called social capital, which depend on inherited capital (social origins), economic capital, financial capital and other types of capital. These social relationships (connections) are the source of many financial and non-financial benefits (Bourdieu, 1986; 2000). Each organization has individuals with connections or social relationships that could be useful and beneficial, either on the board of directors or on the management team. Companies become centers for networking and power in which we can find various influential groups in society (Breton \& Pesqueux, 2006). However, these connections are not one-way relationships. Companies all need influential groups in society in order to obtain the resources they require; the individuals who represent these groups also need businesses. The most telling example of this is corporate funding of political parties.

When they give money to politicians, companies become an essential resource for those politicians and even gain political power, since they control it financially. The search for resources to meet survival needs and become successful has led companies to take a position of unprecedented power in our society. Breton and Pesqueux (2006) argued that there are three levels of relationships between corporations and society: the macro level, which represents the link between companies, states and governments (federal, provincial, regional and municipal); the intermediate level, which focuses on the links between companies, pressure groups and lobbies; and the micro level, consisting of the relationship between companies and their immediate stakeholders such as customers, suppliers, creditors and debtors. Political connections exist at the macro level of the relationship between companies and society, the level that gives more power to the company and brings maximum resources.

Research has demonstrated that companies with political connections perform better financially and have easier access to finances, in both the Canadian context (Dicko \& Breton, 2013a; 2013b; Dicko \& El Ibrami, 2013; Dicko \& Khemakhem, 2015; Khemakhem \& Dicko, 2013) and around the world (Hillman, Zardkoohi, \& Bierman, 1999; Goldman, Rocholl, \& So, 2009; Fisman, 2001; Hillman, 2005; Goldman, Rocholl, \& So, 2013; Li \& Xia, 2013; Houston, Jiang, \& Yuema, 2014; Yan, Wu, \& Wilson, 2014).

Until now, almost no studies have been conducted on financial institutions. They are often seen as a major source of funding for businesses that are not financial institutions. It is therefore difficult to imagine that financial institutions could use their connections to gain access to funding sources. However, financial institutions can use their connections for non-financial activities such as monitoring public policies, the ultimate goal of which would be competitiveness, reducing regulatory barriers and improved performance.

\section{Literature Review and Hypothesis}

The literature on political connections in financial institutions is almost non-existent. To our knowledge, only one author, Dinc (2005), has indirectly addressed this issue by examining loans from government banks during an election campaign. After conducting an international study of 43 emerging market countries, Dinc (2005) found that government-owned banks increased their lending by $11 \%$ in election years, which, according to him, demonstrated the impact of political connections on the behavior of financial institutions. However, several studies have been conducted on the impact of political connections on companies in other industries, and the authors have agreed that such connections can be beneficial for those with the connections (Faccio, 2006). Companies with political connections experience more and easier access to funding, a better chance of winning government contracts (Dicko, 2016) and improved financial performance.

\subsection{The Effect of Political Connections on Companies Other than Financial Institutions}

Several studies have demonstrated a positive relationship between being politically connected and corporate financial performance. In the American context, Goldman et al. (2009) observed positive abnormal returns following the appointment of an administrator with political connections in companies. They proved that after the 2000 U.S. presidential elections, companies connected to the Republican party through their political financial contributions experienced a significant increase in abnormal returns.

In Brazil, Claessens et al. (2008) found similar results to Goldman et al. (2009). They observed that Brazilian companies that had contributed financially to the campaign of candidates elected in the elections held between 1998 and 2002 had abnormal returns that were significantly higher than companies that have not made such contributions. 
In Canada, Dicko, and Breton (2013a) and Dicko and Khemakhem (2015) showed that politically connected Canadian companies performed better financially than non-politically connected companies. Their performance was measured using return on assets and return on equity ratios.

Studies have also been conducted on international samples. Using a sample of firms from 77 countries, Boubakri et al. (2013) found that politically connected firms tended to take more risks than firms that were not politically connected, which means that networked businesses also perform better financially, as risk-taking is associated with improved performance.

As we have mentioned previously, few studies have highlighted the negative impact of political connections on corporate financial performance. We have noted the study of Li and Xia (2013), which demonstrated that before the 2008 financial crisis, political connections had no significant impact on the performance of listed Chinese companies. However, the impact became positive and significant after the 2008 crisis.

Some studies have shown that having political connections allows companies to more easily obtain financing from banks in North America (in the United States, Houston et al., 2014; in Canada, Dicko \& El Ibrami, 2013) and South America (especially Brazil, Claessens et al., 2008) than in Asia (in Thailand, Charumilind et al., 2006; in Taiwan, Chen et al., 2014). These findings illustrate the fact that usually, companies in non-financial industries should solicit more financial institutions to obtain financing.

Though they constitute a source of funding for companies in non-financial industries, financial institutions may themselves need the resources of such companies. Financial institutions are also companies pursuing profit targets. Given the findings of previous studies on companies in non-financial industries, we believe that political connections could also have an impact on financial institutions, but it is important to first understand the factors that influence financial performance besides political connections, as found in the current literature on the subject.

\subsection{Factors Affecting the Solvency and Performance of Financial Institutions}

The studies that have been conducted on determinants of the performance of financial institutions have shown that the ratio of equity to total assets (solvency) is the performance indicator generally used. The size of the firm, as well as merger and acquisition activities also appear to be determinants of financial institutions' performance.

According to Chen and Wong (2004), the factors affecting the financial health of Asian insurance companies are size, investment performance, liquidity and profitability margin. After analyzing Taiwanese financial holdings companies, Shih-Fang and Wen-Min (2006) also concluded that the size of the firm and its merger and acquisition activities were critical to its performance. After performing a longitudinal case study of a U.S. commercial bank, Kozyro (2012) concluded that merger and acquisition activities, reputation, and the quality of directors and the management team were important factors of a financial institution's solvency.

The common theme that emerges from previous studies seems to be the size of the financial institution as a factor in performance. Size could be the result of performance - the more effective the financial institution is, the more it develops and grows. There is also a possible link between investments and merger and acquisition activities that further allows financial institutions to develop. According to international financial regulatory agencies (including the Financial Stability Committee), solvency is the most important factor in measuring the performance and survival of financial institutions.

\subsection{Research Hypothesis}

In our study, we have chosen to examine the effect of political connections on the solvency and financial performance of Canadian financial institutions using the same performance indicators as are generally used for companies in non-financial industries, such as return on assets and return on equity. Our study would be the first, to our knowledge, to examine the impact of political connections on Canadian banks and insurance companies.

If we look at studies of companies in non-financial industries, we could logically expect political connections to have a positive effect on both the solvency and performance of financial institutions. However, it is crucial to take into account the specific character of financial institutions compared to companies in other industries. Banks are often seen as catalysts of economic development (Ahmed \& Rashid, 2012) and an effective governance tool to help monitor the behavior of firms in other industries (Holland, 1999; Holland, 2001; Mezher et al., 2002). Despite the specific nature of financial institutions, both in terms of structure, regulatory constraints and governance (Moudud-Ul-Huq, 2014), we argue that political connections have an impact on performance. We therefore propose the following hypothesis:

Hypothesis: Political connections positively influence the solvency and performance of Canadian financial 
institutions.

\section{Research Methodology}

This study was conducted on a total of 30 Canadian financial institutions (banks and insurance companies) from the S\&P/TSX Composite Index between 2010 to 2014.

\subsection{The Analysis Models and Data Sources}

We have performed our analysis based on the following models:

$$
\begin{aligned}
& \text { Solvency }=\text { political connection }+ \text { performance }+ \text { indebtedness }+ \text { firm size } \\
& \text { Performance }=\text { political connection }+ \text { solvency }+ \text { indebtedness }+ \text { firm size }
\end{aligned}
$$

Model (1) uses solvency as a dependent variable, while model (2) uses performance as its dependent variable. As explanatory variables, we used political connections, financial performance (in the case of model 1), level of debt and size of the firm. The Compustat database was utilized to select the financial institutions studied and some of the financial data. The BoardEx database was employed to collect data in order to measure the political connections variable.

\subsection{The Explained Variables}

Two dependent variables were used:

- Solvency: researchers and international regulatory agencies use the ratio of capital as a measure of bank solvency. This is the ratio of total equity to total assets (Pillar 3 of the Basel Accords and Financial Stability Board report).

- Performance: we have chosen to use market performance (measured by the ratio of the firm's market value over its book value, known generally as market-to-book ratio) and accounting performance (measured by return on assets $[\mathrm{ROA}]$ and return on equity $[\mathrm{ROE}])$.

\subsection{The Explanatory Variable: Political Connections}

A company is considered politically connected when a member of the board of directors, a member of the management team or the majority shareholder is or was a member of parliament (federal or provincial), a member of a ministerial cabinet (federal or provincial) or a member of a political party or a financial contributor to a political party. This definition is used most often in the literature (Faccio, 2006; Golman et al., 2009; Dicko, 2016). In our study, we have adopted this definition, excepting the political party financial contributions item. Our political connections variable takes the value of 1 if the firm is politically connected and 0 otherwise.

\subsection{The Control Variables}

According to the literature, two variables are considered to have the most influence on financial institutions' performance. We have used them in this study as control variables. They are:

- Firm size: measured by the natural logarithm of income

- Level of debt (indebtedness): measured by the ratio of long-term debt to total equity

\section{Analysis Results}

We will first present the results of the descriptive analyses of variance and correlation, followed by the regression analysis.

\subsection{The Results of Descriptive and Variance Analyses}

The descriptive results on frequencies in Table 1 show that the data is distributed almost equally across the years covered by the study (2010, 2011, 2012, 2013 and 2014). We therefore had an average of about 30 observations per year. However, the second part of the table shows that there were more politically connected financial institutions than financial institutions that were not connected (78.8\% versus $21.2 \%)$. 
Table 1. Descriptive statistics

\begin{tabular}{|c|c|c|c|c|c|c|}
\hline \multirow{2}{*}{$\frac{\text { By year }}{\text { Valid }}$} & & \multirow{2}{*}{$\frac{\text { Frequency }}{28}$} & \multirow{2}{*}{$\frac{\text { Percentage }}{19.2}$} & \multicolumn{2}{|r|}{ Valid percentage } & \multirow{2}{*}{$\begin{array}{c}\text { Cumulated percentage } \\
19.2\end{array}$} \\
\hline & Year 2010 & & & & 19.2 & \\
\hline & Year 2011 & 28 & 19.2 & & 19.2 & 38.4 \\
\hline & Year 2012 & 30 & 20.5 & & 20.5 & 58.9 \\
\hline & Year 2013 & 30 & 20.5 & & 20.5 & 79.5 \\
\hline & Year 2014 & 30 & 20.5 & & 20.5 & 100.0 \\
\hline & Total & 146 & 100.0 & & 100.0 & \\
\hline \multicolumn{3}{|c|}{ By the variable of political connections } & Frequency & Percentage & Valid percentage & Cumulated percentage \\
\hline \multirow[t]{3}{*}{ Valid } & Not politica & & 31 & 21.2 & 21.2 & 21.2 \\
\hline & Politically c & & 115 & 78.8 & 78.8 & 100.0 \\
\hline & Total & & 146 & 100.0 & 100.0 & \\
\hline
\end{tabular}

In Table 2, we noted that there was a significant difference between politically connected financial institutions and financial institutions that were not connected in terms of ROA, solvency and firm size. This difference is marginally significant in terms of the market value to book value ratio and was not significant in terms of ROE or debt ratio (indebtedness). These first results indicate that political connections affect the solvency and performance of financial institutions.

Table 2. Analysis of variances results

\begin{tabular}{|c|c|c|c|c|c|c|}
\hline \multicolumn{2}{|c|}{ Factor: Political connections } & \multirow{2}{*}{$\frac{\text { Sum of squares }}{0.060}$} & \multirow{2}{*}{$\frac{\mathrm{ddl}}{1}$} & \multirow{2}{*}{$\begin{array}{c}\text { Mean square } \\
0.060\end{array}$} & \multirow{2}{*}{$\frac{F}{33.894}$} & \multirow{2}{*}{$\frac{\text { Sig. }}{0.000}$} \\
\hline ROA & Intergroups & & & & & \\
\hline & Intragroup & 0.254 & 144 & 0.002 & & \\
\hline & Total & 0.313 & 145 & & & \\
\hline \multirow[t]{3}{*}{ ROE } & Intergroups & 0.030 & 1 & 0.030 & 0.022 & 0.883 \\
\hline & Intragroup & 196.427 & 144 & 1.364 & & \\
\hline & Total & 196.456 & 145 & & & \\
\hline \multirow[t]{3}{*}{ Solvency } & Intergroups & 1.817 & 1 & 1.817 & 30.983 & 0.000 \\
\hline & Intragroup & 8.443 & 144 & 0.059 & & \\
\hline & Total & 10.260 & 145 & & & \\
\hline \multirow[t]{3}{*}{ Firm size } & Intergroups & 124.270 & 1 & 124.270 & 33.762 & 0.000 \\
\hline & Intragroup & 530.036 & 144 & 3.681 & & \\
\hline & Total & 654.306 & 145 & & & \\
\hline \multirow[t]{3}{*}{ Indebtedness } & Intergroups & 0.054 & 1 & 0.054 & 0.002 & 0.962 \\
\hline & Intragroup & 3337.558 & 144 & 23.177 & & \\
\hline & Total & 3337.612 & 145 & & & \\
\hline \multirow[t]{3}{*}{ Market-to-book ratio } & Intergroups & 144.607 & 1 & 144.607 & 3.093 & 0.081 \\
\hline & Intragroup & 6731.490 & 144 & 46.746 & & \\
\hline & Total & 6876.097 & 145 & & & \\
\hline \multirow[t]{3}{*}{ Year } & Intergroups & 0.915 & 1 & 0.915 & 0.456 & 0.501 \\
\hline & Intragroup & 288.839 & 144 & 2.006 & & \\
\hline & Total & 289.753 & 145 & & & \\
\hline
\end{tabular}

In addition, we also noted that there was no significant difference between the financial institutions that were connected and not connected in terms of years. This means that the data were distributed equally over the five years covered by the study in terms of having or not having political ties. Consequently, the relationship between the dependent, independent and control variables was the same throughout the period of the study, regardless of the year. For this reason, we decided to remove the year variable for the rest of the analysis. It should also be mentioned that this decision was supported by the fact that we conducted parallel analyses by integrating the year variable and the results were the same as those obtained without this variable.

\subsection{The Results of Correlation Analysis and the Multicollinearity Test}

The results of the correlation analysis presented in Table 3 show that the political connections variable was positively and significantly correlated with firm size. Political connections were negatively and significantly 
correlated with ROA and solvency, which contradicted the hypothesis that political connections positively influence the financial performance of the firm. Perhaps findings that are valid for companies in other industries are not valid for financial institutions. This finding would be normal, since financial institutions are generally not subject to the same rules of operation and governance as companies in other industries. In general, financial institutions, particularly banks, are subject to international rules and regulations, such as the Basel Accords. We must note that the correlation between political connections and market-to-book ratio was positive and not significant, while ROE and debt ratio (indebtedness) was negative and not significant.

Table 3. Pearson correlation analysis results

\begin{tabular}{|c|c|c|c|c|c|c|c|}
\hline Variables & 1 & 2 & 3 & 4 & 5 & 6 & 7 \\
\hline 1 Political connections & 1 & & & & & & \\
\hline 2 Firm size & $0.436^{* *}$ & 1 & & & & & \\
\hline $3 \mathrm{ROA}$ & $-0.436^{* *}$ & $-0.336^{* *}$ & 1 & & & & \\
\hline $4 \mathrm{ROE}$ & -0.012 & 0.024 & 0.028 & 1 & & & \\
\hline 5 Market-to-book ratio & 0.145 & -0.014 & -0.139 & $0.484^{* *}$ & 1 & & \\
\hline 6 Solvency & $-0.421^{* *}$ & $-0.681^{* *}$ & $0.525^{* *}$ & -0.031 & 0.115 & 1 & \\
\hline 7 Indebtedness & -0.004 & -0.027 & -0.012 & $0.960^{* *}$ & $0.369^{* *}$ & -0.076 & 1 \\
\hline
\end{tabular}

** The correlation is significant at level 0.01 (two sides).

* The correlation is significant at level 0.05 (two sides).

b. Calculation impossible because at least one of the variables is a constant.

The results of the correlation analysis also demonstrated a potential multicollinearity problem between some of our independent variables. This was the case for the very significant correlation between firm size and solvency (-68\%), ROA and solvency (52.5\%), and ROE and debt (96\%). These correlations between the independent variables are considered problematic because they were above $50 \%$. We will perform additional testing to measure the effect and to control this multicollinearity.

\subsection{The Results of Regression Analysis}

To analyze the two models, we presented previously, we performed a linear regression analysis of data from a five-year period (2010-2014). Four regression analyses were performed using the following dependent variables: solvency, ROA, ROE and market-to-book ratio.

\subsubsection{The Linear Regression Analysis Results with Solvency as a Dependent Variable}

According to Table 4, the political connections variable had a negative but not significant influence on the solvency of financial institutions, which is in line with the results of the correlation analysis but contradicts the variance analysis results and invalidates our hypothesis. Political connections therefore positively influence the solvency of financial institutions.

In contrast, market-to-book ratio, ROE and ROA positively and significantly affected the solvency of Canadian financial institutions. This influence was negative and significant in terms of indebtedness and firm size.

In the Canadian context, it seems that the only elements that had an impact on the solvency of financial institutions were related to financial indicators. Not only were these results consistent with the results of previous research, but they also confirmed the recommendations of international experts on the issue. Following the 2008 financial crisis, experts from the international Financial Stability Board recommended raising the minimum solvency ratio that financial institutions must maintain. These new requirements were included in Basel III in order to prevent future financial crises caused by a lack of liquidity in banks. 
Table 4. Linear regression analysis results dependent variable: solvency

\begin{tabular}{|c|c|c|c|c|c|c|}
\hline \multirow[b]{2}{*}{ Model } & & \multicolumn{2}{|c|}{ Non-standardized coefficients } & \multirow{2}{*}{$\frac{\text { Standardized coefficients }}{\text { Beta }}$} & \multirow[b]{2}{*}{$\mathrm{T}$} & \multirow[b]{2}{*}{ Sig. } \\
\hline & & $\mathrm{B}$ & Standard error & & & \\
\hline & (Constant) & 0.808 & 0.067 & & 11.967 & 0.000 \\
\hline & Political connections & -0.032 & 0.041 & -0.050 & -0.795 & 0.428 \\
\hline & Firm size & -0.073 & 0.008 & -0.585 & -9.308 & 0.000 \\
\hline & Market-to-book ratio & 0.005 & 0.003 & 0.141 & 2.030 & 0.044 \\
\hline & Indebtedness & -0.035 & 0.012 & -0.633 & -2.899 & 0.004 \\
\hline & $\mathrm{ROA}$ & 1.741 & 0.352 & 0.304 & 4.951 & 0.000 \\
\hline & ROE & 0.117 & 0.054 & 0.513 & 2.190 & 0.030 \\
\hline \multicolumn{7}{|c|}{$\mathrm{R} 2=0.627$} \\
\hline \multicolumn{7}{|c|}{ Adjusted R2 = 0.611} \\
\hline \multicolumn{7}{|c|}{ P value of model $=0.000$} \\
\hline
\end{tabular}

\subsubsection{The Linear Regression Analysis Results with ROA as a Dependent Variable}

Table 5 shows that political connections negatively and significantly influenced the ROA of financial institutions, which does not confirm our hypothesis and indicates that political connections positively influence the performance of financial institutions.

ROE and solvency in particular positively and significantly influenced the ROA of Canadian financial institutions. This influence was negative and significant for indebtedness and market-to-book ratio.

Table 5. Linear regression analysis results dependent variable: ROA

\begin{tabular}{|c|c|c|c|c|c|c|}
\hline \multirow[b]{2}{*}{ Model } & & \multicolumn{2}{|c|}{ Non-standardized coefficients } & \multirow{2}{*}{$\begin{array}{c}\text { Standardized coefficients } \\
\text { Beta }\end{array}$} & \multirow[b]{2}{*}{$\mathrm{t}$} & \multirow[b]{2}{*}{ Sig. } \\
\hline & & $\mathrm{B}$ & Standard error & & & \\
\hline & (Constant) & 0.023 & 0.021 & & 1.096 & 0.275 \\
\hline & Political connections & -0.023 & 0.009 & -0.201 & -2.583 & 0.011 \\
\hline & Firm size & 0.001 & 0.002 & 0.053 & 0.516 & 0.607 \\
\hline & Market-to-book ratio & -0.002 & 0.001 & -0.306 & -3.558 & 0.001 \\
\hline & Indebtedness & -0.005 & 0.003 & -0.514 & -1.818 & 0.071 \\
\hline & ROE & 0.027 & 0.012 & 0.681 & 2.285 & 0.024 \\
\hline & Solvency & 0.086 & 0.017 & 0.493 & 4.951 & 0.000 \\
\hline \multicolumn{7}{|c|}{$\mathrm{R} 2=0.396$} \\
\hline \multicolumn{7}{|c|}{ Adjusted R2 $=0.370$} \\
\hline \multicolumn{7}{|c|}{ 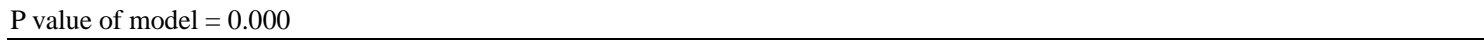 } \\
\hline
\end{tabular}

\subsubsection{The Linear Regression Analysis Results with ROE as a Dependent Variable}

As for ROA, political connections negatively influenced the ROE for financial institutions, hence the non-confirmation of our hypothesis. However, market-to-book ratio, firm size, indebtedness, ROA and solvency positively and significantly influenced the ROE of Canadian financial institutions (see Table 6 for these results).

Table 6. Linear regression analysis results dependent variable: ROE

\begin{tabular}{llccccc}
\hline & & \multicolumn{2}{c}{ Non-standardized coefficients } & Standardized coefficients & \multirow{2}{*}{ Sig. } \\
\cline { 3 - 5 } Model & $\mathrm{B}$ & Standard error & Beta & & t \\
\hline & (Constant) & -0.616 & 0.140 & & -4.390 & 0.000 \\
& Political connections & -0.105 & 0.063 & -0.037 & -1.676 & 0.096 \\
& Firm size & 0.071 & 0.014 & 0.129 & 4.922 & 0.000 \\
Market-to-book ratio & 0.026 & 0.004 & 0.155 & 7.268 & 0.000 \\
Indebtedness & 0.221 & 0.005 & 0.911 & 44.463 & 0.000 \\
Solvency & 0.284 & 0.130 & 0.065 & 2.190 & 0.030 \\
ROA & 1.331 & 0.583 & 0.053 & 2.285 & 0.024 \\
\hline
\end{tabular}

$\mathrm{R} 2=0.953$

Adjusted R2 $=0.951$

P value of model $=0.000$ 


\subsubsection{The Linear Regression Analysis Results with Market-to-Book Ratio as a Dependent Variable}

Unlike the other two performance indicators (ROA and ROE), Table 7 shows that the market-to-book ratio was positively and significantly influenced by financial institutions' political connections, which partly confirms our hypothesis.

ROE and solvency also positively and significantly influenced market-to-book ratio. Firm size, indebtedness and ROA negatively but significantly influenced this ratio.

Table 7. Linear regression analysis results dependent variable: Market-to-book ratio

\begin{tabular}{|c|c|c|c|c|c|c|}
\hline \multirow{2}{*}{\multicolumn{2}{|c|}{ Model }} & \multicolumn{2}{|c|}{ Non-standardized coefficients } & \multirow{2}{*}{$\begin{array}{c}\text { Standardized coefficients } \\
\text { Beta }\end{array}$} & \multirow[b]{2}{*}{$\mathrm{t}$} & \multirow[b]{2}{*}{ Sig. } \\
\hline & & $\mathrm{B}$ & Standard error & & & \\
\hline & (Constant) & 1.082 & 2.993 & & 0.362 & 0.718 \\
\hline & Political connections & 3.071 & 1.238 & 0.183 & 2.479 & 0.014 \\
\hline & Firm size & -0.407 & 0.310 & -0.126 & -1.311 & 0.192 \\
\hline & Indebtedness & -1.901 & 0.353 & -1.325 & -5.384 & 0.000 \\
\hline & Solvency & 5.285 & 2.604 & 0.204 & 2.030 & 0.044 \\
\hline & ROA & -40.452 & 11.370 & -0.273 & -3.558 & 0.001 \\
\hline & ROE & 10.501 & 1.445 & 1.775 & 7.268 & 0.000 \\
\hline \multicolumn{7}{|c|}{$\mathrm{R} 2=0.461$} \\
\hline \multicolumn{7}{|c|}{ Adjusted R2 = 0.437} \\
\hline \multicolumn{7}{|c|}{$P$ value of model $=0.000$} \\
\hline
\end{tabular}

The three previous subsections indicate that the political connections of financial institutions had a negative impact on their financial accounting performance indicators (ROA and ROE) while positively influencing market performance (market-to-book ratio). Do investors welcome the fact that financial institutions have such connections? The answer is unclear, but what is certain is that financial institutions control the main resource usually sought by other types of companies-financial resources. It would be interesting to know the key resources financial institutions require in order to better understand the utility of political connections for them. It is possible that financial institutions have to be politically connected to control regulations, for example. It is also possible that financial institutions use other political actions (besides those discussed in this study, such as lobbying activities) to achieve their goals.

\subsection{The Results of Supplementary Control Analysis}

To better understand the effects of the multicollinearity problem identified above, we repeated all four regression analyses by removing the problematic variables (ROA, ROE, solvency and market-to-book ratio). The results were almost the same as with those variables included. These results are not presented in this paper but are available upon request.

\section{Conclusion and Discussion}

The results of our regression analysis showed that only the market-to-book ratio was positively and significantly influenced by the political connections of Canadian financial institutions. ROA, ROE and solvency were negatively influenced by political connections. These results partially confirmed our hypothesis and partially supported previous findings related to companies in other industries, which have shown that political connections have a positive effect on financial performance (Dicko \& Breton, 2013a; Dicko \& El Ibrami, 2013; Dicko \& Khemakhem, 2015).

Yet it is perhaps natural that we did not obtain the same results as in the case of companies in other industries. Financial institutions have different operating structures and governance than companies in other industries. In addition to meeting the standards and regulations that companies in non-financial industries are subject to, financial institutions often must also comply with international regulations, forcing them to be more rigorous in their operations. Following this logic, it is understandable that the financial performance of financial institutions was not influenced by their political connections. These connections may instead have an effect on other aspects of their operations, such as controlling regulations or governance mechanisms. It is also possible that financial institutions utilize political connections to maintain contact with companies in other industries. In this case, the benefits of such connections would be indirect.

Nevertheless, these results are most likely evidence of the effectiveness of strict international regulations that 
banks in particular are subject to. Banking solvency requirements are defined and established through international agreements such as the Basel Accords. On the other hand, these findings could mean that to have a direct positive effect on performance, the political connections of financial institutions must be made internationally instead of nationally.

Since only the link between political connections and market-to-book ratio was positive and significant (according to the results of the regression analysis), we could conclude that market investors seem to have appreciated the political intervention of several governments to rescue banks at the outbreak of the 2008 financial crisis. To be sure, however, a longitudinal study of several years before and after 2008 should be conducted.

Along these lines, it would be interesting in future research to examine the effect of political connections on other elements of financial institutions, such as the quality of governance before the 2008 crisis as well as after. Future research could also look into other political actions that financial institutions may take, such as lobbying or making financial contributions to political parties.

Finally, the main weakness of this study was that the sample included banks as well as insurance companies. To fully identify the effects of international regulations and distinguish them from other influences, in future research it would be appropriate to focus only on international banking institutions and to include banks from several countries.

\section{References}

Agrawal, A., \& Knoeber, C. R. (2001). Do Some Outside Directors Play a Political Role? Journal of Law and Economics, 44(1), 179-198. http://dx.doi.org/10.2307/2331397

Ahmed, J. U., \& Rashid, Md. A. (2012). Role of Financial Institutions in Financing Small and Medium Entreprises: A Study in Garo Hills of Meghalaya. Journal of Commerce \& Accounting Research, 1(4), 7-23.

Ang, J. S., Ding, D. K., \& Thong, T. Y. (2013). Political Connections and Firm Value. Asian Development Review, 30(2), 131-166. http://dx.doi.org/10.1162/ADEV_a_00018

Bierman, L. (1999). Corporate political strategies and firm performance: Indications of firm-specific benefits from personal service in the U.S. government. Strategic Management Journal, 20(1), 67-81. http://dx.doi.org/10.1002/(SICI)1097-0266(199901)20:1<67::AID-SMJ22>3.0.CO;2-T

Bona-Sánchez, C., Pérez-Alemán, J., \& Santana-Martín, D. J. (2014). Politically Connected Firms and Earnings Informativeness in the Controlling versus Minority Shareholders Context: European Evidence. Corporate Governance: An International Review, 22(4), 330-346. http://dx.doi.org/10.1111/corg.12064

Boubakri, N., Mansi, S. A., \& Saffar, W. (2013). Political Institutions. Connectedness. and Corporate Risk-Taking. Journal of International Business Studies, 44, 195-215. http://dx.doi.org/10.1057/jibs.2013.2

Bourdieu, P. (1986). The Forms of Capital. In J. G. Richardson (Ed.), Handbook of Theory and Research for the Sociology of Education (pp. 241-258).

Bourdieu, P. (2000). Les structures sociales de l'économie. Paris: Éditions du Seuil.

Breton, G., \& Pesqueux, Y. (2006). Business in society or an integrated vision of governance. Society and Business Review, 1(1), 7-27. http://dx.doi.org/10.1108/17465680610643319

Brockman, P., Rui, O. M., \& Zou, H. (2013). Institutions and the performance of politically connected M\&As. Journal of International Business Studies, 44, 833-852. http://dx.doi.org/10.1057/jibs.2013.37

Burris, V. (2005). Interlocking Directorates and Political Cohesion among Corporate Elites. American Journal of Sociology, 111(1), 249-283. http://dx.doi.org/10.1086/428817

Chaney, P. K., Faccio, M., \& Parsley, D. (2011). The Quality of Accounting Information in Politically Connected Firms. Journal of Accounting and Economics, 51, 58-76. http://dx.doi.org/10.1016/j.jacceco.2010.07.003

Charumilind, C., Kali, R., \& Wiwattanakantang, Y. (2006). Connected Lending: Thailand before the Financial Crisis. Journal of Business, 79(1), 181-217. http://dx.doi.org/10.1086/497410

Chen, C. P., Ding, Y., \& Kim, C. (Francis). (2010). High-level Politically Connected Firms. Corruption. and Analyst Forecast Accuracy around the World. Journal of International Business Studies, 41, 1505-1524. http://dx.doi.org/10.1057/jibs.2010.27

Chen, R., \& Wong, K. A. (2004). The determinants of financial health of asian insurance companies. Journal of Risk and Insurance, 71(3), 469-499. http://dx.doi.org/10.1111/j.0022-4367.2004.00099.x 
Chen, Y. S., Shen, C. H., \& Lin, C. Y. (2014). The Benefits of Political Connection: Evidence from Individual Bank-Loan Contracts. J Financ Serv Res, 45, 287-305. http://dx.doi.org/10.1007/s10693-013-0167-1

Claessens, S., Feijen, E., \& Laeven, L. (2008). Political Connections and Preferential Access to Finance: The Role of Campaign Contributions. Journal of Financial Economics, 88, 554-580. http://dx.doi.org/10.1016/j.jfineco.2006.11.003

Dicko, S., \& Breton, G. (2013a). Do Directors' Connections Really Matter? International Academic Research Journal of Business and Management, 1(7), 1-19.

Dicko, S., \& Breton, G. (2013b). Social Networks of the Board Members and Acquisition of Resources by the Firm: A Case Study. International Academic Research Journal of Business and Management, 1(8), 30-47.

Dicko, S., \& El Ibrami, H. (2013). Directors' Connections, Financial Resources and Performance: An In-Depth Analysis of Canadian Companies. International Journal of Business and Management, 8(10), 1-14. http://dx.doi.org/10.5539/ijbm.v8n10p1

Dicko, S., \& Khemakhem, H. (2015). S\&P/TSX 300 Companies' Political Connections. Compliance with Board of Directors Regulations and Financial Performance. International Journal of Business and Management, 10(1), 14-24. http://dx.doi.org/10.5539/ijbm.v10n1p14

Dicko, S. (2011). Réseaux de relations sociales des membres du conseil d'administration et acquisition de ressources: Le cas de Power Corporation du Canada. Montréal: PhD Thesis, Université du Québec à Montréal.

Dicko, S. (2016). Firms Political Connections and Winning Government Contracts. International Journal of Economics and Finance, 8(2), 19-32. http://dx.doi.org/10.5539/ijef.v8n2p19

Dinc, I. S. (2005). Politicians and banks: Political influences on government-owned banks in emerging markets. Journal of Financial Economics, 77, 453-479. http://dx.doi.org/10.1016/j.jfineco.2004.06.011

Faccio, M. (2006). Politically Connected Firms. The American Economic Review, 96(1), 369-386. http://dx.doi.org/10.1257/000282806776157704

Faccio, M., Masulis, R. W., \& McConnell, J. J. (2006). Political Connections and Corporate Bailouts. The Journal of Finance, LXI(6), 2597-2635. http://dx.doi.org/10.1111/j.1540-6261.2006.01000.x

Fisman, R. (2001). Estimating the Value of Political Connections. The American Economic Review, 91(4), 1095-1102. http://dx.doi.org/10.1257/aer.91.4.1095

Goldman, E., Rocholl, J., \& So, J. (2009). Do Politically Connected Boards Affect Firm Value? The Review of Financial Studies, 22(6), 2331-2360. http://dx.doi.org/10.1093/rfs/hhn088

Goldman, E., Rocholl, J., \& So, J. (2013). Politically Connected Boards of Directors and the Allocation of Procurement Contracts. Review of Finance, 17, 1617-1648. http://dx.doi.org/10.1093/rof/rfs039

Hillman, A. J., Zardkhoohi, A., \& Bierman, L. (1999). Corporate political strategies and firm performance: Indications of firm-specific benefits from personal service in the U.S. government. Strategic Management Journal, 20, 67-81. http://dx.doi.org/10.1002/(SICI)1097-0266(199901)20:1<67::AID-SMJ22>3.0.CO;2-T

Hillman, A. J. (2005). Politicians on the Board of Directors: Do Connections Affect the Bottom Line? Journal of Management, 31(3), 464-481. http://dx.doi.org/10.1177/0149206304272187

Holland, J. (1999). Financial Reporting. Private Disclosure and the Corporate Governance Role of Financial Institutions. Journal of Management and Governance, 3(2), 161-187. http://dx.doi.org/10.1023/A:1009991609633

Holland, J. (2001). Financial Institutions. Intangibles and Corporate Governance. Accounting. Auditing \& Accountability Journal, 14(4), 497-529. http://dx.doi.org/10.1108/EUM0000000005871

Houston, J., Jiang, L. L., Lin, C., \& Yuema. (2014). Political Connections and the Cost of Bank Loans. Journal of Accounting Research, 52(1), 193-243. http://dx.doi.org/10.1111/1475-679X.12038

Khemakhem, H., \& Dicko, S. (2013). Directors' Political Connections and Compliance with Board of Directors Regulations: The Case of S\&P/TSX 300 Companies. International Journal of Business and Management, $8(24), 117-125$. http://dx.doi.org/10.5539/ijbm.v8n24p117

Kozyro, D. (2012). A case study of commercial bank solvency during a global financial crisis. PhD Thesis, Indiana University of Pennsylvania. 
Li, A., \& Xia, X. (2013). Political Connections. Financial Crisis and Firm's Value: Evidence from Chinese Listed $\begin{array}{lllll}\text { Firms. International Journal of Business and Management, 8(18), } & \text { 63-77. }\end{array}$ http://dx.doi.org/10.5539/ijbm.v8n18p63

Maman, D. (2000). Who Accumulates Directorships of Big Business Firms in Israel? Organizational Structure. Social Capital and Human Capital. Human Relations, 53(5), 603-629. http://dx.doi.org/10.1177/0018726700535001

Mezher, T., Jamali, D., \& Zreik, C. (2002). The role of financial institutions in the sustainable development of Lebanon. Sustainable Development, 10(2), 69-78. http://dx.doi.org/10.1002/sd.183

Moudud-Ul-Huq, S. (2014). Corporate Governance Practices in Banking and Non-Banking Financial Institutions of Bangladesh. Research Note. The IUP Journal of Corporate Governance, 13(4), 61-70.

Pfeffer, J., \& Salancik, G. R. (1978). The External Control of Organizations: A Resource Dependence Perspective. New York: Harper \& Row.

Pfeffer, J. (1981). Power in Organizations. Marshfield, Mass, Pitman.

Pfeffer, J. (1982). Organizations and Organization Theory. Stanford University: Pitman (Boston, London, Melbourne, Toronto).

Shih-Fang, L., \& Wen-Min, L. (2006). Does size matter? Finding the profitability and marketability benchmark of financial holding companies. Asia - Pacific Journal of Operational Research, 23(2), 229-246. http://dx.doi.org/10.1142/S0217595906000930

Wang, C. (2014). Political Connections of the Boards of Directors and Department of Defense Contractors' Excessive Profits. Journal of Public Procurement, 14(1), 96-122.

Yang, F., Wilson, C., \& Wu, Z. (2014). Investor Perceptions of the Benefits of Political Connections: Evidence from China's A-share Premiums. International Journal of Managerial Finance, 10(3), 312-331. http://dx.doi.org/10.1108/JMMF-08-2012-0093

Zardkoohi, A. (1985). On the political participation of the firm in the electoral process. Southern Economic Journal, 51, 804-817. http://dx.doi.org/10.2307/1057881

\section{Notes}

Note 1. Mark Carney, Chairman, Financial Stability Board, Bank for International Settlements, Report of the Enhanced Disclosure Task Force, October 29, 2012.

Note 2. Annabelle Williams. Taking on bank solvency risk. Report, 2015. www.investmentweek.co.uk.

\section{Copyrights}

Copyright for this article is retained by the author(s), with first publication rights granted to the journal.

This is an open-access article distributed under the terms and conditions of the Creative Commons Attribution license (http://creativecommons.org/licenses/by/4.0/). 